Горбань А.В., Довгаль І.І., Крижсановська С. І., Найденов А.І.

\title{
ОСОБЛИВОСТІ ПРОГНОЗУВАННЯ СТАНУ СУДНОВОГО ОБЛАДНАННЯ РІЧКОВОГО ТА МОРСЬКОГО ТРАНСПОРТУ
}

Основне протиріччя, яке лежить в основі наукових досліджень у напрямку підвищення ефективності експлуатації засобів річкового та морського транспорту, полягає, з одного боку, у необхідності підвищення технічної готовності суднового обладнання до використання за призначенням та безвідмовності його функиіонування.

3 іншого боку, намагання максимального здешевлення транспортних перевезень, призводить до зменшення кількості контрольних заходів, спрощення їх процедури. У такому аспекті, розроблення нових методів технічної експлуатаџіï обладнання на основі застосування сучасних автоматизованих процедур визначення періодичності та обсягу діагностування є актуальним.

Отже, вирішенню підляає актуальне науково-прикладне завдання щцодо розроблення процедури визначення доцільних термінів технічного діагностування суднового обладнання при на основі прогнозування технічного стану обладнання.

Наведені результати моделювання підтверджують адекватність моделі прочесу експлуатації суднового обладнання річкового та морського транспорту, яка базується на ідеї прогнозуючого контролю індивідуальної надійності зразка суднового обладнання на основі канонічного розкладання випадкового прочесу з урахуванням похибок апріорних вимірювань, щуо дозволяє реалізувати зазначену модель в умовах експлуатації судна при мінімумі діагностичних даних точно визначаючи випадковий прочес у точках контролю та забезпечуючи мінімум середнього квадрата похибки наближення у проміжках між цฺими точками

Неповнота апріорної інформації може знизити точність прогнозування, або взагалі зробити неможсливм прогнозування стану суднового обладнання. У такому випадку постає необхідність врахування неповноти інформації контролю у процедурі вирімення задачі прогнозування, а також оцінки їі впливу на точність одержаних результатів.

У статті розглянуто особливості вирімення задачі прогнозування поза межами апріорного знання процесу, а саме практичний приклад індивідуального прогнозування зміни зазору штоку та направляючої втулки клапана на основі лінійного канонічного подання скалярного апостеріорного процесу на області, не охопленій статистикою, тобто поза межами апріорного знання прочесу

Ключові слова: апріорне знання прочесу, канонічне розкладання випадкового прочесу, прогнозуючий контроль, індивідуальна надійність, модель, річковий та морський транспорт.

Постановка проблеми. На практиці, особливо в умовах рейсів, коли дуже часто немає фізичної можливості щодо застосування високоточного обладнання, в умовах відсутності кваліфікованого персоналу та часових обмежень щодо здійснення контролю функціонування обладнання, така повна інформація щодо досліджуваної реалізації випадкового процесу часто відсутня [1,2]. 
Неповнота інформації обумовлюється, у першу чергу, наявністю похибок вимірювань параметрів обладнання $x(\mu), \mu=\overline{1, k}$.

Крім того, втрати інформації можуть виникати внаслідок недосконалості системи реєстрації даних контролю та внаслідок неможливості здійснення контролю у певних умовах. Також, у тих випадках, коли реєструється лише сам факт справності контрольованого об’єкта, кількісні значення параметра вимірювання можуть взагалі бути відсутніми.

Мета статті. Тому актуальним $€$ завдання вирішення задачі прогнозування поза межами апріорного знання процесу. Наведення особливостей прогнозування стану суднового обладнання річкового та морського транспорту поза межами апріорного знання процесу $є$ темою статті.

\section{Виклад основного матеріалу. Похибки апріорних вимірювань.}

Така ситуація $є$ достатньо характерною для рейсів, оскільки під час тривалого рейсу досить складно, а іноді і неможливо, здійснювати контроль параметрів обладнання 3 застосуванням високоточних метрологічних приладів. Введемо деякі припущення стосовно вирішення задачі щодо оцінки впливу похибок апріорних вимірювань на результати прогнозування. Нехай відомі усі параметри реалізації до останнього вимірювання $x(\mu), \mu=\overline{1, k}$, причому зазначені дані виміряні з деякою випадковою похибкою $Y$, яка має постійну у часі щільність розподілу $f(y)$, з математичним очікуванням $m_{y}$ та дисперсією $D_{y}$. Також будемо вважати, що істинне значення параметра вимірювання та відповідна похибка його вимірювання можуть розглядатися як незалежні випадкові величини $[3,4]$.

За цих умов, якщо у деякий момент $t_{\mu}$ здійснити контроль випадкового процесу $X(t)$, то замість істинного значення процесу буде спостерігатися реалізація деякої іншої випадкової величини [4,5]

$$
z(\mu)=x(\mu)+y(\mu)
$$

Для апостеріорного випадкового процесу при $\mu=1$ визначаємо

$$
X_{z}^{(1)}(i)=m(i)+(z(1)-m(1)) \varphi_{1}(i)+\sum_{v=2}^{i} V_{v} \varphi_{v}(i), i=\overline{1, I}
$$

При одержанні даних повторного контролю у момент $\mu=2$ апостеріорний процес буде мати вигляд [5]

$$
X_{z}^{(2)}(i)=m_{z}^{(1)}(i)+\left(z(2)-m_{z}^{(1)}(2)\right) \varphi_{2}(i)+\sum_{v=3}^{i} V_{v} \varphi_{v}(i), i=\overline{1, I}
$$

Відповідно вираз для апостеріорного процесу набуде вигляду

$$
X_{z}^{(2)}(i)=m_{z}^{(2)}(i)+\sum_{v=3}^{i} V_{v} \varphi_{v}(i), i=\overline{1, I}
$$


Загальний вираз для апостеріорного процесу, визначеного на основі $k$ моментів контролю з похибками буде мати вигляд [6]

$$
X_{z}^{(k)}(i)=m_{z}^{(k)}(i)+\sum_{v=k+1}^{i} V_{v} \varphi_{v}(i), i=\overline{1, I}
$$

3 (5) видно, що похибки вимірювання впливають лише на величину математичного очікування апостеріорного процесу. Звідси слідує, що похибка індивідуального прогнозу, яка виникає внаслідок похибок вимірювань значень контрольованої реалізації, може бути визначена як різниця математичних очікувань реального та ідеального апостеріорних процесів. Результуюча похибка на $k$-му кроці контролю визначається рекурентним чином на основі співвідношення [6,7]

$$
\begin{gathered}
\delta_{1}(i)=y_{1} \varphi_{1}(i), i=\overline{1, I} \\
\delta_{k}(i)=\delta_{k-1}(i)+\left(y_{k}-\delta_{k-1}(k)\right) \varphi_{k}(i), i=\overline{k, I}, i=\overline{2, I} .
\end{gathered}
$$

Істинність (1) - (6) перевіряється шляхом моделювання зносу втулки циліндра (табл. 1) при сталих значеннях істинного зносу $X$, випадкових значеннях похибки вимірювання $Y$ та результатів вимірювання $Z$ (всього змодельовано 4 варіанти), яке підтверджує той факт, що похибки діагностування впливають лише на величину математичного очікування прогнозованої величини [8].

Таблиця 1

Моделювання зносу втулки циліндра з урахуванням похибок вимірів

\begin{tabular}{|l|l|l|l|l|l|l|l|l|l|l|l|}
\hline & \multicolumn{7}{|c|}{ Напрацювання, год } & \multirow{2}{*}{ M } & \\
\cline { 2 - 10 } & 0 & 4000 & 8000 & 12000 & 16000 & 20000 & 4000 & 28000 & 32000 & & \\
\hline & 740,01 & 740,73 & 741,16 & 741,61 & 741,98 & 742,21 & 742,54 & 742,68 & 742,7 & 741,735 & 0,886 \\
\hline 1 & $-0,01$ & $-0,04$ & 0 & $-0,05$ & $-0,04$ & 0,04 & $-0,04$ & 0,03 & 0,04 & $-0,007$ & 0,001 \\
\hline 1 & 740 & 740,69 & 741,16 & 741,56 & 741,94 & 742,25 & 742,5 & 742,71 & 742,74 & 741,728 & 0,914 \\
\hline 2 & $-0,04$ & $-0,01$ & 0 & 0,03 & $-0,05$ & 0,03 & $-0,04$ & $-0,03$ & 0,04 & $-0,007$ & 0,001 \\
\hline 2 & 739,97 & 740,72 & 741,16 & 741,64 & 741,93 & 742,24 & 742,5 & 742,65 & 742,74 & 741,728 & 0,901 \\
\hline 3 & 0,03 & 0 & $-0,05$ & $-0,05$ & 0,04 & 0,05 & $-0,02$ & 0,04 & 0 & 0,004 & 0,001 \\
\hline 3 & 740,04 & 740,73 & 741,11 & 741,56 & 742,02 & 742,26 & 742,52 & 742,72 & 742,7 & 741,739 & 0,897 \\
\hline 4 & $-0,05$ & $-0,01$ & $-0,04$ & 0 & $-0,04$ & 0,03 & $-0,01$ & 0 & 0,01 & $-0,012$ & 0,001 \\
\hline & 739,96 & 740,72 & 741,12 & 741,61 & 741,94 & 742,24 & 742,53 & 742,68 & 742,71 & 741,723 & 0,918 \\
\hline
\end{tabular}

Таким чином, результати моделювання підтверджують адекватність моделі процесу експлуатації суднового обладнання річкового та морського транспо, яка базується на ідеї прогнозуючого контролю індивідуальної надійності зразка суднового обладнання на основі канонічного розкладання випадкового процесу 3 урахуванням похибок апріорних 
вимірювань, що дозволяє реалізувати зазначену модель в умовах експлуатації судна при мінімумі діагностичних даних точно визначаючи випадковий процес у точках контролю та забезпечуючи мінімум середнього квадрата похибки наближення у проміжках між цими точками [9].

Відсутність окремих даних реалізації. Найбільш часто така ситуація виникає при здійсненні допускового контролю працездатності об'єкта (як правило під час рейсу), коли реєструється лише факт справності чи несправності, без деталізації окремих параметрів процесу експлуатації. Таким чином, про зразок обладнання, який визнано справним у момент контролю $t_{k}$, відомо лише, що він безвідмовно працював з початку експлуатації (рейсу) до моменту останнього контролю. При цьому конкретні значення параметрів експлуатації $€$ невідомими.

У такому варіанті задача прогнозу може бути сформульована наступним чином. Нехай апріорний випадковий процес $X(t)$ задано канонічним поданням $[7,9]$

$$
X\left(t_{i}\right)=m\left(t_{i}\right)+\sum_{v=1}^{i} V_{v} \varphi_{v}\left(t_{i}\right), \overline{i=1, I}
$$

У результаті контролю конкретної реалізації цього процесу $x(\mu)$ у моменти $t_{\mu}, \mu=\overline{1, k}, k<I$, стало відомо, що дана реалізація жодного разу не вийшла за межі області допуску $[a, b]$, але точні ії значення невідомі. Необхідно визначити апостеріорні характеристики надійності зразка обладнання, зміни стану якого описуються даною реалізацією.

У такому випаду застосування моделей, наведених вище, неможливе. Відсутність значень контрольованої реалізації не дозволяє скористатися формулами математичного очікування апостеріорного процесу і унеможливлює його моделювання [10].

Для того щоб у таких умовах сформувати апостеріорний процес, можна скористатися принципом відбору реалізацій. Як вже зазначалося, всі реалізації апостеріорного процесу на інтервалі $\left[t_{1}, t_{k}\right]$ повинні бути у межах $[a, b]$. Тому можна забезпечити виконання заданої умови шляхом моделювання апріорного процесу і відбору тих реалізацій, які задовольняють визначеній умові.

Прогнозування поза межами апріорного знання процесу. Вищеописаний підхід охоплює випадки лише задачі прогнозу, для якої є характерним наявність апріорного знання процесу на інтервалі $[0, T]$. Тому поняття неповноти інформації торкається лише даних контролю. При цьому вважається, що апріорна інформація відома повністю. Однак, для експлуатації судна на рейсах в умовах відсутності достатньої статистики використання суднового обладнання більш важливою $є$ інша задача, за якої статистична інформація про процес існує на інтервалі $[0, T]$, а прогноз необхідно здійснити на деякому інтервалі $\left[T, T^{\prime}\right]$, тобто поза межами доступної статистики. У такому випадку обсяг апріорної інформації $\epsilon$ недостатнім [11].

Для вирішення такої задачі визначимо випадковий процес $X(t)$, який задано канонічним поданням на дискретному ряді точок $t_{i}, i=\overline{1, I}$. У результаті контролю стану зразка обладнання одержано реалізацію процесу $x(\mu), \mu=\overline{1, k}, k \geq 1$. Необхідно 
спрогнозувати надійність або технічний стан цього об'єкта для деякого моменту $t_{I^{\prime}}>t_{I}$, який лежить поза межами області статистичних характеристик процесу.

Очевидно, що чим більшим є інтервал $[0, T]$, то тим більшим є обсяг інформації про характер процесу зміни стану зразка обладнання і тим достовірнішим є прогноз. У свою чергу достовірність прогнозування залежить від заданого моменту часу у області $\left[T, T^{\prime}\right]$.

Визначивши реалізацію випадкового процесу можна побачити, що у випадку незначного впливу випадкової складової процесу $y(t)$, процес може вважатися детермінованим, у протилежному випадку його необхідно розглядати, як стохастичний. Вибір того чи іншого підходу здійснюється за результатами аналізу зовнішніх умов та режимів використання об'єкта. У такому випадку є необхідність пояснення принципу, за яким буде здійснено вибір підходу [12].

Разом 3 тим, розглядаючи окрему реалізацію випадкового процесу експлуатації конкретного зразка суднового обладнання, результати спостереження за яким спотворюються лише похибками вимірювань контрольованого параметра, $\epsilon$ можливість застосування детермінованого підходу щодо визначення параметрів випадкового процесу.

Серед основних методів вирішення задачі прогнозування (екстраполяції, регресійного аналізу та статистичної класифікації) для вирішення задачі детермінованого прогнозу найбільш придатними є методи екстраполяції, які грунтуються на переносі на майбутнє тенденцій минулого [10-12].

При вирішенні задачі детермінованого прогнозування технічного стану шуканими характеристиками є значення діагностичних параметрів $z_{j}\left(t_{n+m}\right), j=\overline{1, s}, m=\overline{1, k} \in\left[T, T^{\prime}\right]$, а при прогнозуванні надійності - запас працездатності об'єкта $\left|z_{j}\left(t_{n+m}\right)-z_{j}^{\text {доn }}\right|_{\text {min }}$, де $s-$ число діагностичних параметрів; $n$ - останній момент контролю у області $[0, T] ; k$ - останній момент контролю у області $\left[T, T^{\prime}\right]$.

На практиці досить важко отримати аналітичні вирази для узагальненого діагностичного параметра. Більш доцільним є одержання деякої апроксимації реалізації випадкового процесу поліномом виду

$$
F(a, t)=a_{0}+a_{1} t+a_{2} t^{2}+\ldots+a_{\beta} t^{\beta}
$$

де $a_{i}=f_{i}(z), i=\overline{0, \beta}$;

$\beta$ - ступінь поліному.

Таким чином будуються окремі траєкторії (реалізації випадкового процесу) функціонування зразка суднового обладнання у області $\left[T, T^{\prime}\right]$, тобто в області, яку не було покрито апріорними спостереженнями і у якій неможливо розробити прогноз поведінки зразка обладнання на основі канонічного подання процесу, опираючись лише на статистичні дані спостережень за аналогічним класом об'єктів.

Достовірність такого підходу підтверджується шляхом моделювання, де, на підставі знання статистики зносу поршня моделюються подальші реалізації розвитку процесу зносу та прогнозується індивідуальна поведінка окремого зразка (поршня) за методом канонічного подання випадкового процесу. Порівняння точності прогнозування з реальною реалізацією дає змогу оцінити ефективність запропонованого удосконалення методу прогнозування параметра технічного стану зразка суднового обладнання (табл. 2) [12]. 
Таблиця 2

Порівняльний аналіз методів прогнозування

\begin{tabular}{|c|c|}
\hline Метод прогнозування & $\begin{array}{c}\text { Середнє відхилення від } \\
\text { реальної реалізації, } \%\end{array}$ \\
\hline $\begin{array}{c}\text { За середнім значенням (математичним } \\
\text { очікуванням) }\end{array}$ & $35 . .65$ \\
\hline За ковзним середнім & $30 \ldots 60$ \\
\hline МГУА & $8 \ldots 15$ \\
\hline Поліноміальна екстраполяція & $10 . .20$ \\
\hline $\begin{array}{c}\text { Канонічне подання випадкового } \\
\text { процесу }\end{array}$ & $6 \ldots 12$ \\
\hline
\end{tabular}

Для ілюстрації наведених теоретичних положень розглянемо практичний приклад індивідуального прогнозування зміни зазору штоку та направляючої втулки клапана на основі лінійного канонічного подання скалярного апостеріорного процесу на області, не охопленій статистикою, тобто поза межами апріорного знання процесу.

Для цього проаналізуємо статистичні дані щодо зносу аналогічних вузлів, які визначалися 3 періодичністю 4000 год під час планових технічних оглядів двигуна на проміжку часу 0 - 16000 год. Припустимо, що решта значень у проміжку 16000 - 20000 год, на відміну від табл. А.1, є невідомими (табл. 3) [12, 13].

Таблиця 3

Результати замірів зазору штоку та направляючої втулки клапана

\begin{tabular}{|c|c|c|c|c|c|c|c|c|c|c|}
\hline \multirow{3}{*}{ № вузла } & \multicolumn{9}{|c|}{ Напрацювання, год } \\
\cline { 2 - 10 } & 0 & 4000 & 8000 & 12000 & 16000 & 20000 & 24000 & 28000 \\
\cline { 2 - 10 } & 1 & 2 & 3 & 4 & 5 & 6 & 7 & 8 \\
\hline & 0.123 & 0.157 & 0.175 & 0.204 & 0.223 & - & - & - \\
\hline 1 & 0.159 & 0.162 & 0.214 & 0.219 & - & - & - \\
\hline 2 & 0.120 & 0.184 & 0.200 & 0.226 & - & - & - \\
\hline 3 & 0.118 & 0.147 & 0.184 & - & - & - & - \\
\hline 4 & 0.124 & 0.157 & 0.190 & 0.198 & 0.216 & - & - & - \\
\hline 5 & 0.116 & 0.162 & 0.180 & 0.209 & 0.218 & - & - & - \\
\hline 6 & 0.130 & 0.162 & 0.182 & 0.196 & 0.234 & - & - & - \\
\hline 7 & 0.121 & 0.169 & 0.179 & 0.189 & 0.217 & - & - & - \\
\hline 8 & 0.108 & 0.141 & 0.158 & 0.212 & 0.230 & - & - & - \\
\hline 9 & 0.119 & 0.144 & 0.168 & 0.215 & 0.229 & - & - & - \\
\hline 10 & 0.121 & 0.149 & 0.165 & 0.187 & 0.206 & - & - & - \\
\hline
\end{tabular}

Цей масив (табл. 2) складає початкову базу прогнозування. Зазначені дані табл. 2 можуть бути зображені у вигляді реалізацій деякого випадкового процесу (рис. 1). Штриховою лінією, як і раніше, на цьому рисунку позначено математичне очікування наведених реалізацій. 


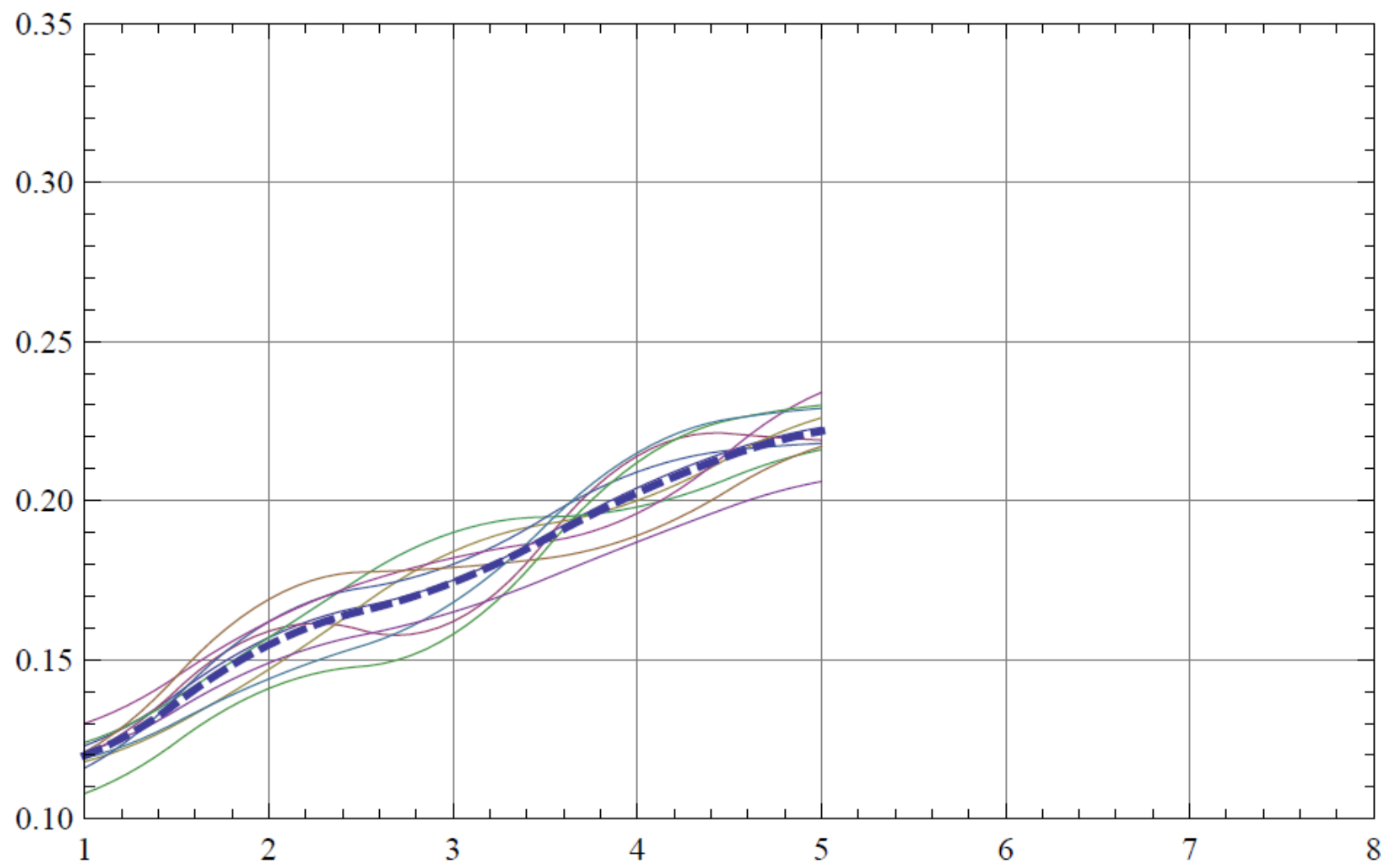

Рисунок 1 - Динаміка зміни зазору штоку та направляючої втулки клапана (по обмеженій вибірці)

Необхідно визначити прогнозовані значення зазору на період 5 - 8 .

Відновлюємо кожну траєкторію табл.3 за допомогою екстраполюючих поліномів (у найпростішому випадку поліномами 1-го порядку), після чого отримуємо табл. 4 (рис. 2) [13].

Таблиця 4

Відновлені дані замірів зазору

\begin{tabular}{|c|c|c|c|c|c|c|c|c|c|}
\hline \multirow{2}{*}{ № вузла } & \multicolumn{9}{|c|}{ Напрацювання, год } \\
\cline { 2 - 9 } & 0 & 4000 & 8000 & 12000 & 16000 & 20000 & 24000 & 28000 \\
\cline { 2 - 9 } & \multicolumn{7}{|c|}{ Порядковий номер спостережень } \\
\hline & 1 & 2 & 3 & 4 & 5 & 6 & 7 & 8 \\
\hline 1 & 0.123 & 0.157 & 0.175 & 0.204 & 0.223 & 0.242 & 0.261 & 0.280 \\
\hline 2 & 0.120 & 0.159 & 0.162 & 0.214 & 0.219 & 0.224 & 0.229 & 0.234 \\
\hline 3 & 0.118 & 0.147 & 0.184 & 0.200 & 0.226 & 0.252 & 0.278 & 0.304 \\
\hline 4 & 0.124 & 0.157 & 0.190 & 0.198 & 0.216 & 0.234 & 0.252 & 0.270 \\
\hline 5 & 0.116 & 0.162 & 0.180 & 0.209 & 0.218 & 0.227 & 0.236 & 0.245 \\
\hline 6 & 0.130 & 0.162 & 0.182 & 0.196 & 0.234 & 0.272 & 0.310 & 0.348 \\
\hline 7 & 0.121 & 0.169 & 0.179 & 0.189 & 0.217 & 0.245 & 0.273 & 0.301 \\
\hline 8 & 0.108 & 0.141 & 0.158 & 0.212 & 0.230 & 0.248 & 0.266 & 0.284 \\
\hline 9 & 0.119 & 0.144 & 0.168 & 0.215 & 0.229 & 0.243 & 0.257 & 0.271 \\
\hline 10 & 0.121 & 0.149 & 0.165 & 0.187 & 0.206 & 0.225 & 0.244 & 0.263 \\
\hline
\end{tabular}




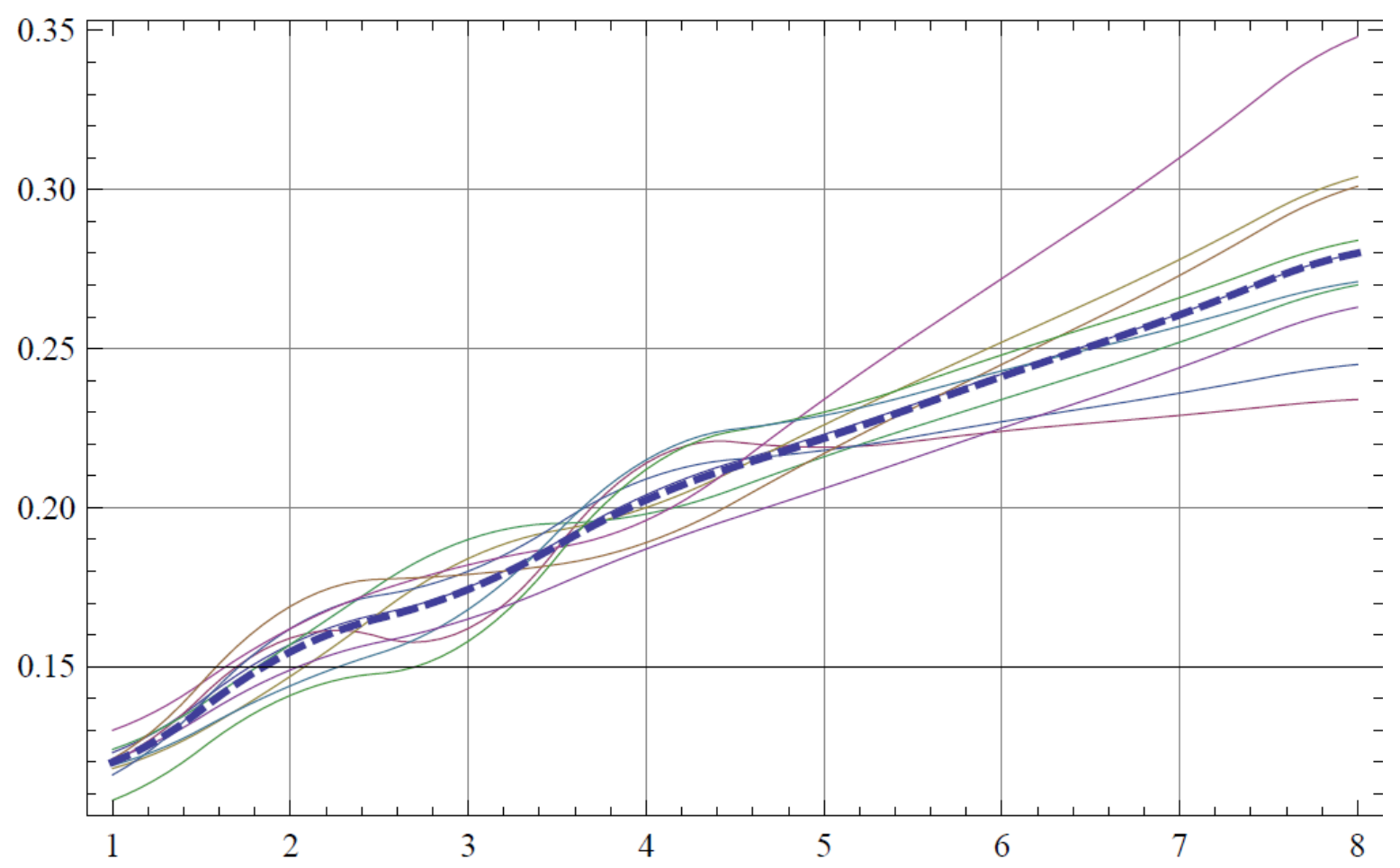

Рисунок 2 - Відновлені дані зазору штоку та направляючої втулки клапана

У такому випадку координатні функції випадкового процесу будуть мати вигляд (рис.

3)

$\varphi_{v}(i)=\left[\begin{array}{cccccccc}1 & 0.887 & 1.02 & -0.873 & -0.0582 & 0.757 & 1.57 & 2.39 \\ 0 & 1 & 0.571 & -0.418 & -0.22 & -0.022 & 0.175 & 0.373 \\ 0 & 0 & 1 & -0.402 & 0.0026 & 0.407 & 0.812 & 1.22 \\ 0 & 0 & 0 & 1 & 0.392 & -0.215 & -0.823 & -1.43 \\ 0 & 0 & 0 & 0 & 1 & 1.42 & 1.83 & 2.25 \\ 0 & 0 & 0 & 0 & 0 & 1 & 1.55 & 2.1 \\ 0 & 0 & 0 & 0 & 0 & 0 & 1 & 1.38 \\ 0 & 0 & 0 & 0 & 0 & 0 & 0 & 1\end{array}\right]$.




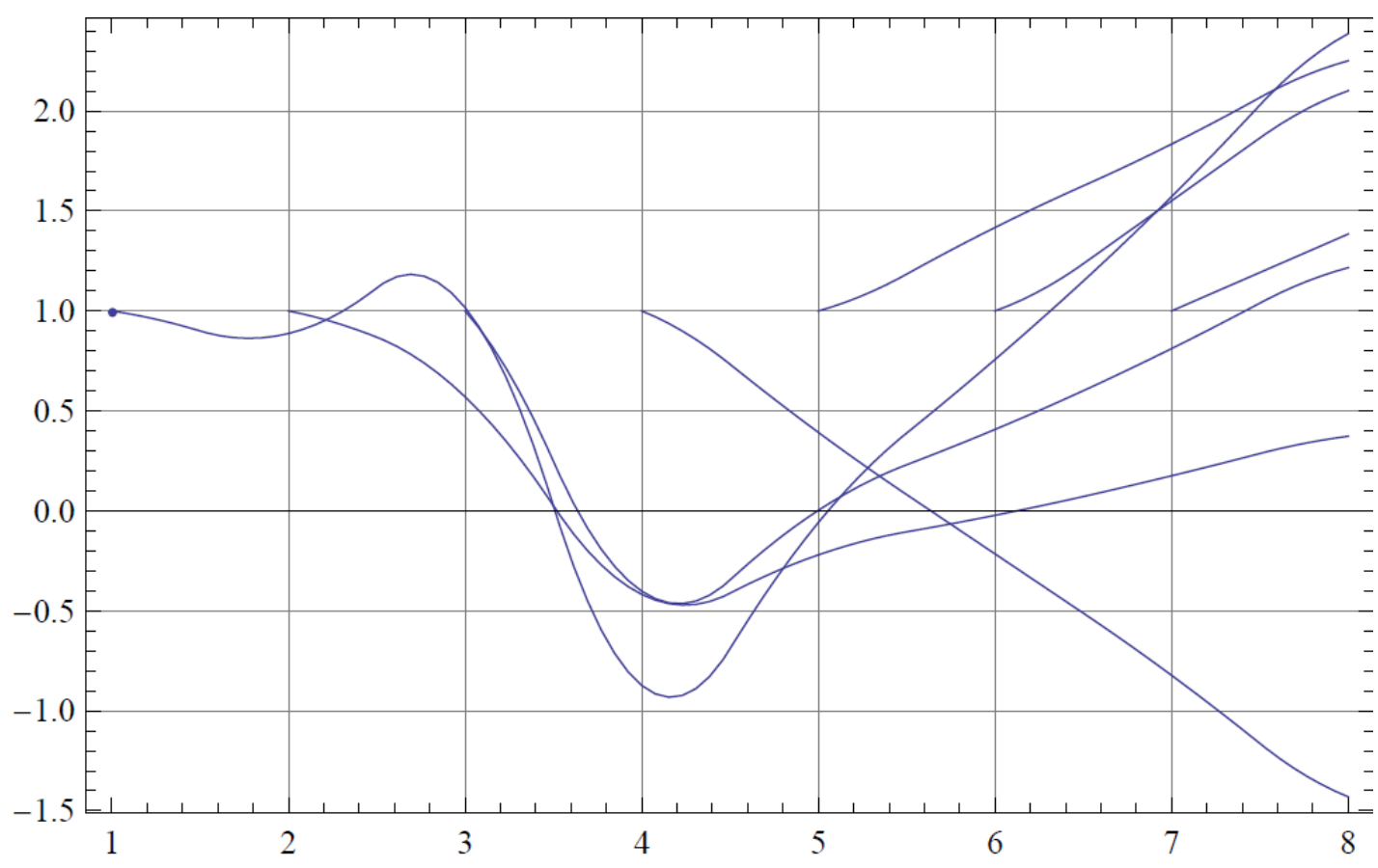

Рисунок 3 - Координатні функції випадкового процесу

Можна побачити, що на області визначеної статистики ці функції співпадають. Розбіжності починаються лише там, де дані були відновлені за допомогою екстраполяції.

Таблиця 5

Результати прогнозування

\begin{tabular}{|c|c|c|c|c|c|c|c|c|}
\hline \multirow{2}{*}{$\begin{array}{c}\text { Кількість } \\
\text { врахованих } \\
\text { апріорних }\end{array}$} & \multicolumn{8}{|c|}{ Напрацювання, год } \\
\cline { 2 - 9 } & 0 & 4000 & 8000 & 12000 & 16000 & 20000 & 24000 & 28000 \\
\cline { 2 - 9 } & \multicolumn{8}{|c|}{ Парядковий номер спостережень } \\
\hline 1 & 1 & 2 & 3 & 4 & 5 & 6 & 7 & 8 \\
\hline 2 & 0.119 & 0.153 & 0.171 & 0.198 & 0.217 & 0.235 & 0.254 & 0.272 \\
\hline 3 & 0.119 & 0.144 & 0.159 & 0.196 & 0.214 & 0.230 & 0.247 & 0.263 \\
\hline 4 & 0.119 & 0.144 & 0.168 & 0.207 & 0.224 & 0.242 & 0.259 & 0.276 \\
\hline & 0.119 & 0.144 & 0.168 & 0.215 & 0.224 & 0.237 & 0.251 & 0.265 \\
\hline & 0.119 & 0.144 & 0.168 & 0.215 & 0.229 & 0.248 & 0.250 & 0.276 \\
\hline
\end{tabular}

Як і раніше, перевіримо можливості методу щодо індивідуального прогнозування, для чого оберемо одну з траєкторій (наприклад траєкторію № 9) у якості тестової. Припустимо, що, як і раніше, нам відомі лише перші 4 даних спостережень у моменти часу $1-4$. Виникає необхідність визначити значення зазору для моментів часу $5-8$.

Застосувавши підхід для скалярного апостеріорного процесу, одержимо результати для прикладу, який розглядається у цьому додатку (табл. 5 та рис. 4) [13]. 


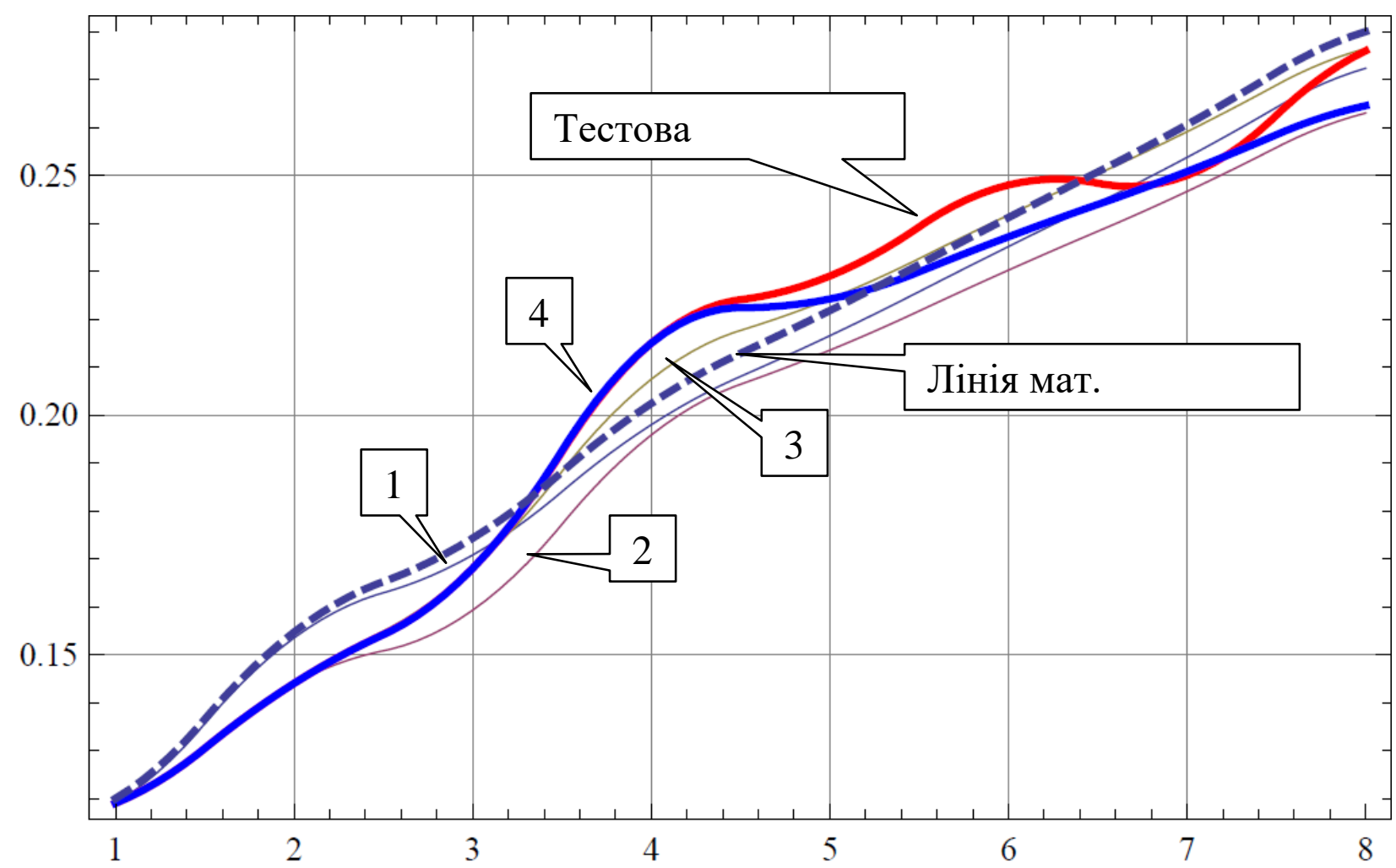

Рисунок 4 - Результати прогнозування

Визначивши оцінки диперсії для прогнозованих траєкторій при заданих умовах (вибірка обмежена 5-ма точками контролю, відомі перші 4 значення зазорів) обчислимо точність прогнозу (табл. 6).

Таблиця 6

Оцінка точності прогнозу, \%

\begin{tabular}{|c|c|c|c|c|c|c|c|c|}
\hline & \multicolumn{8}{|c|}{ Напрацювання, год } \\
\cline { 2 - 9 } Відхилення & 0 & 4000 & 8000 & 12000 & 16000 & 20000 & 24000 & 28000 \\
\cline { 2 - 9 } & \multicolumn{8}{|c|}{ Порядковий номер спостережень } \\
\cline { 2 - 9 } & 1 & 2 & 3 & 4 & 5 & 6 & 7 & 8 \\
\hline$\delta$ & 0.0 & 0.0 & 0.0 & 0.0 & 5.7 & 6.8 & 12.5 & 16.6 \\
\hline
\end{tabular}

Висновки. Зазначена загальна модель процесу експлуатації суднового обладнання при трансокеанських вантажних перевезеннях базується на ідеї прогнозуючого контролю. При цьому перевагою вирішення задачі прогнозування на основі канонічного подання Пугачова $\epsilon$ те, що воно забезпечує вирішення задачі моделювання як скалярних так і векторних процесів 3 залежними складовими. Єдиним обмеженням, яке накладається на досліджуваний випадковий процес $є$ скінченність його дисперсії. Опис випадкового процесу на основі його канонічного подання точно визначає випадковий процес у точках контролю та забезпечує мінімум середнього квадрата похибки наближення у проміжках між цими точками.

Дослідження впливу похибок апріорних вимірювань у запропонованій загальній моделі експлуатації суднового обладнання дозволяє зробити висновок про те, що похибки апріорних вимірювань впливають лише на величину математичного очікування апостеріорного процесу. 3 цього слідує, що похибка індивідуального прогнозу, яка виникає внаслідок похибок вимірювань значень контрольованої реалізації, може бути визначена як різниця математичних очікувань реального та ідеального апостеріорних процесів. Достовірність зазначеного результату у роботі підтверджено моделюванням на прикладі втулки циліндра 3 урахуванням похибок вимірів. 


\section{ЛІТЕРАТУРА}

1. Кудрицкий В.Д. Фильтрация, экстраполяция и распознавание реализаций случайных функций / В.Д. Кудрицкий // - К.:ФАДА, ЛТД, 2001. - 176 с.

2. Полянин А.Д. Справочник по линейным уравнениям математической физики / А.Д. Полянин // - М.: Физматлит, 2001. - 362 с.

3. Острейковский В.А. Теория надежности / В.А. Острейковский // - М.: Высшая школа, 2003. - 463 c.

4. Кобелева А.С. Модели и информационное обеспечение системы управления техническим состоянием судового энергетического оборудования: дисс. ... канд. техн. наук: 05.13.09 / А.С. Кобелева // - СПб: ФГОУ ВПО СПГУВК, 2007. - 166 с.

5. Никитин А.М. Управление технической эксплуатацией судов / А.М. Никитин // - СПб: Белл, 2004. - 188 c.

6. Корн Г.А. Справочник по математике (для научных работников и инженеров) / Г.А. Корн, Т.М. Корн // - М.: Наука, 1973. - 832 с.

7. Перов В.М. Реновація суден / В. М. Перов // - Миколаїв: НУК, 2006. - 148 с.

8. Козлов А.В. Пути повышения эффективности управления судовыми энергетическими процессами / А.В. Козлов // - СПб: Судостроение, 2002. - 194 с.

9. Опыт эксплуатации элементов цилиндро-поршневой группы судовых двигателей Бурмейстер и Вайн [Электронный pecypc] // Режим доступа: http://sealibrary.ru/burmeyster.html.

10. Calder N. Marine Diesel Engines / Nigel Calder // - International Marine / Ragged Mountain Press, 2006. -256 p.

11. Рябинин И.А. Надежность и безопасность структурно-сложных систем. - 2-е изд. / И.А. Рябинин // - СПб.: Издательство Санкт-Петербургского университета, 2007. $276 \mathrm{c}$

12. Гуменюк В.М. Надежность и диагностика электротехнических систем / В.М. Гуменюк // - Владивосток: Изд-во Дальневост. гос. техн. ун-та, 2010. - 218 с.

13. Богомя В.І., Горбань А.В., Павленко М.А., Тимочко О.І., Тимощук О.М.. За заг. ред. О. М. Тимощук. Особливості системного підходу до вирішення наукових завдань експлуатації суднового обладнання: підручник. Київ, 2018. 305 с.

\section{Горбань А.В., Довгаль І.І., Крижановська С. І., Найденов А.И. ОСОБЕННОСТИ ПРОГНОЗИРОВАНИЯ СОСТОЯНИЯ СУДОВОГО ОБОРУДОВАНИЯ РЕЧНОГО И МОРСКОГО ТРАНСПОРТА}

Основное противоречие, которое лежит в основе научных исследований в направлении повышения эффективности эксплуатации средств речного и морского транспорта, заключается, с одной сторонь, в необходимости повышения технической готовности судового оборудования $\kappa$ использованию по назначению и безотказности его функиионирования.

C другой стороны, попытки максимального удешевления транспортных перевозок, приводит к уменьшению количества контрольных мероприятий, упрощение их процедуры. $B$ таком аспекте, разработка новых методов технической эксплуатации оборудования на основе применения современных автоматизированных процедур определения периодичности и объема диагностирования является актуальным.

Таким образом, решению подлежит актуальная научно-прикладная задача по разработке прочедуры определения иелесообразных сроков технического диагностирования судового оборудования при на основе прогнозирования технического состояния оборудования.

Приведенные результаты моделирования подтверждают адекватность модели проиесса эксплуатации судового оборудования речного и морского транспорта, которая базируется на идее прогнозирующего контроля индивидуальной надежности образиа судового оборудования на основе канонического разложения случайного прочесса с учетом погрешностей априорных измерений. 
Эта идея позволяет реализовать указанную модель в условиях эксплуатации судна при минимуме диагностических данных, точно определяя случайный процесс в точках контроля и обеспечивая минимум среднего квадрата ошибки приближения в промежутках между этими точками

Неполнота априорной информачии может снизить точность прогнозирования, или вообще сделать невозможным прогнозирование состояния судового оборудования. В таком случае возникает необходимость учета неполноты информачии контроля в прочедуре решения задачи прогнозирования, а также оченки ее влияния на точность полученных результатов.

B статье рассмотрены особенности решения задачи прогнозирования вне априорного знания процесса, а именно практический пример индивидуального прогнозирования изменения зазора штока и направляющей втулки клапана на основе линейного канонического представления скалярного апостериорного прочесса на области, не охваченных статистикой, то есть за пределами априорного знания процесса

Ключевые слова: априорное знание прочесса, каноническое разложение случайного прочесса, прогнозирующий контроль, индивидуальная надежность, модель, речной $u$ морской транспорт.

\section{Gorban A.V., Dovgal I.I., Krizhanovska S. I., Naidenov A.I. FEATURES OF FORECASTING THE CONDITION OF VESSEL EQUIPMENT OF RIVER AND SEA TRANSPORT}

The main contradiction that underlies scientific research in the direction of improving the efficiency of river and sea transport is, on the one hand, the need to increase the technical readiness of ship equipment for its intended use and its smooth operation.

On the other hand, attempts to maximize the cost of transportation, leads to a reduction in the number of control measures, simplification of their procedure. In this aspect, the development of new methods of technical operation of equipment based on the use of modern automated procedures for determining the frequency and scope of diagnosis is relevant.

Thus, the solution is subject to the actual scientific and applied task of developing a procedure for determining the appropriate timing of technical diagnostics of ship equipment on the basis of forecasting the technical condition of the equipment.

These simulation results confirm the adequacy of the model of the process of operation of ship equipment of river and sea transport, which is based on the idea of predictive control of individual reliability of a sample of ship equipment based on canonical decomposition of a random process taking into account a priori measurement errors.

This idea allows to implement the specified model in the conditions of operation of the vessel at a minimum of diagnostic data, precisely defining random process in control points and providing a minimum of an average square of an error of approach in intervals between these points.

Incomplete a priori information can reduce the accuracy of forecasting, or make it impossible to predict the condition of ship equipment. In this case, there is a need to take into account the incompleteness of control information in the procedure for solving the problem of forecasting, as well as to assess its impact on the accuracy of the results.

The article considers the peculiarities of solving the problem of forecasting outside the a priori knowledge of the process, namely a practical example of individual forecasting of the change of the stem gap and the valve guide sleeve based on a linear canonical representation of the scalar a posteriori process in areas not covered by statistics.

Keywords: a priori knowledge of the process, canonical decomposition of a random process, predictive control, individual reliability, model, river and sea transport. 